\title{
MANAGEMENT OF DIGITIZATION IN THE ECONOMIC HIGH SCHOOL EDUCATION SYSTEM IN THE RURAL ENVIRONMENT IN ROMANIA DURING THE SARS-COV-2 PANDEMIC PERIOD
}

\author{
Costel CEOCEA ${ }^{a}$, Geanina-Valentina LUPU ${ }^{b}$, Alina Bianca POP \\ Aurel Mihail ȚîT $U^{d, e^{*}}$ \\ ${ }^{a}$ Vasile Alecsandri University of Bacău, România, \\ ${ }^{b}$ Universitatea de Științe Agronomice și Medicină Veterinară București, România, \\ 'SC TechnoCAD SA, Baia Mare, România, \\ ${ }^{d}$ Lucian Blaga University of Sibiu, România, \\ ${ }^{e}$ Academy of Romanian Scientist, Bucharest, România
}

DOI: $10.24818 / \mathrm{IMC} / 2020 / 02.13$

\begin{abstract}
Education is a strategic interest for Romania and the concept of digitization must be implemented as soon as possible in this field. This is all the more important in the current situation caused by the SARS-CoV-2 pandemic. The reality demonstrated by the exceptional situation that the Romanian education is going through underlines the structural problems of this system. From a methodological point of view, this paper is based on a case study, which also includes a questionnaire, conducted during the suspension of courses with students from a technological high school in rural areas, focusing on teaching economic subjects. Analyzing and interpreting the data obtained during the study highlights the shortcomings related to technical and digital equipment, internet connectivity, low motivation for learning and, we can add, the specific mentality, which make online education difficult to achieve.
\end{abstract}

KEYWORDS: digitization, education system, SARS-CoV-2 pandemic, management.

\section{INTRODUCTION}

Digitization is one of the most important aspects of the industrial revolution 4.0. Internationally, data science, Big Data, Cloud Computing, Deep / Broad Machine Learning, cognitive robotics, CyberPhysical Systems have a special boost. The Internet is developed globally, the next step is the Internet of Things. Communication systems are implementing the 5G generation, web services are advancing rapidly to the Web 3.0 generation, and manufacturing systems have reached the Industry 4.0 generation. Moreover, the Society 5.0 program has appeared in Japan, which aims at the impact of technology on man and society (Diac, 2019).

Since 2011, Industry 4.0 harmoniously and efficiently intertwines the virtual and physical worlds of production, machines, systems and sensors to communicate with each other, to exchange information and to control each other (Bologa, 2019). At EU level, this concept refers to a combination of physical and cybernetic systems to participate in autonomous production processes. Industry 4.0 is highlighted in China by the Made in China 2025 concept. The Innovation 25 plan is introduced in Japan to achieve the same Industry 4.0 concept. The concept of Internet of Thing (IoT) developed in the United States and that of Smart Manufacturing is an intelligent production process for factory optimization, sustainable production and intelligent supply based on cost reduction and efficiency (Amza et al., 2018).

\footnotetext{
"Corresponding author. E-mail address: mihail.titu@ulbsibiu.ro
} 
There are studies and analyzes of Romanian researchers in different fields that highlight these concerns. For example, in the field of engineering, there is a study on a finite element model. The researchers found that anticipating these variables is experimentally costly in terms of time, but also financially. With this information, the finite element model becomes the most favorable and most useful alternative in all aspects (Pop et al., 2019). Another example refers to the advanced concept of product quality planning (APQP), where products manufactured by aviation, space and defense organizations need to be continuously improved in accordance with safety, security, reliability and maintainability (Pop et al., 2018). And the examples can go on.

\section{THE STAGE OF DIGITIZATION IN THE ROMANIAN EDUCATION SYSTEM}

Several prestigious institutions in Romania have started discussions on the implementation of the 4.0 revolution on various sectors of society. Among them we can list: the Romanian Academic Management Society (SAMRO), the Romanian Academy and the Association for Economic-Social Studies and Forecasts (ASPES).

SAMRO is one of the institutions that takes steps at the highest academic level to achieve, through a parliamentary initiative of the Synthesis of the Romanian Economic Model in the EU. RomaniaHorizon 2040 and the adoption of a document by the Parliament appropriating the development directions of Romania from the perspective of 2040. In a debate spread over several years, 14 until now, from November 2018 to February 2020, topics were addressed that they looked at important aspects of the Romanian society such as: demography, education, research, national ecosystem, agriculture, food industry, management, innovation, new technologies.

Regarding the Romanian Academy, it initiated a series of discussions that focused on artificial intelligence (AI), information and communication technology (ICT) and the responsibilities of robotics in Romanian society. In 2019, at the proposal of academician Ioan Dumitrache, the reflection group on the impact of the evolution of ICT and AI on man and society was set up. The think tank identified favorable factors for Industry 4.0 such as the share of the ICT sector in Gross Domestic Product (GDP), the development of e-commerce, the development of high-speed Internet infrastructure, numerous mobile phones among rural and urban citizens, but also the attraction young people towards these technologies. Among the negative factors are identified: the exodus of brains and labor in various fields, which shows a shortage of highly skilled labor in many sectors of the economy, insufficient computerization of public administration, excessive bureaucratization in many sectors of the economy.

Romania is in line with the trend set by the European Union regarding digitalization. The digital transformation is accelerated by the accelerated progress of new technologies such as robotics, artificial intelligence, cloud computing and blockchain technologies (European Commission, 2020). About $80 \%$ of young people use the internet for social activities. Internet access has increased exponentially in recent years. But the use of technology for education does not keep pace. Only $82 \%$ of primary and secondary schools in the EU were connected to the broadband internet and not all teachers have the skills and willingness to use digital tools in education.

With the increasing digitalization of all aspects of life, the rapid development of technology is sounding the alarm about the state of implementation of government strategies and policies. And they risk being overtaken by the rapidity of technological change. Figure 1 demonstrates what kind of strategies EU Member States are implementing: specific or broader, which include elements of digital education. About half of the states are pursuing a broader strategy, with these countries being from south-eastern Europe. Another 18 states in Western, Central and Northern Europe have a specific strategy (European Commission, 2018).

The strategy on modernizing the educational infrastructure 2017-2023 provides for the implementation of the SIPOCA 6 project in the Strategic Framework for educational infrastructure and support in strategic planning of education and training - INFRAED GIS tool - Geospatial Information System for education (http://sig.forhe.ro/, 2020). 


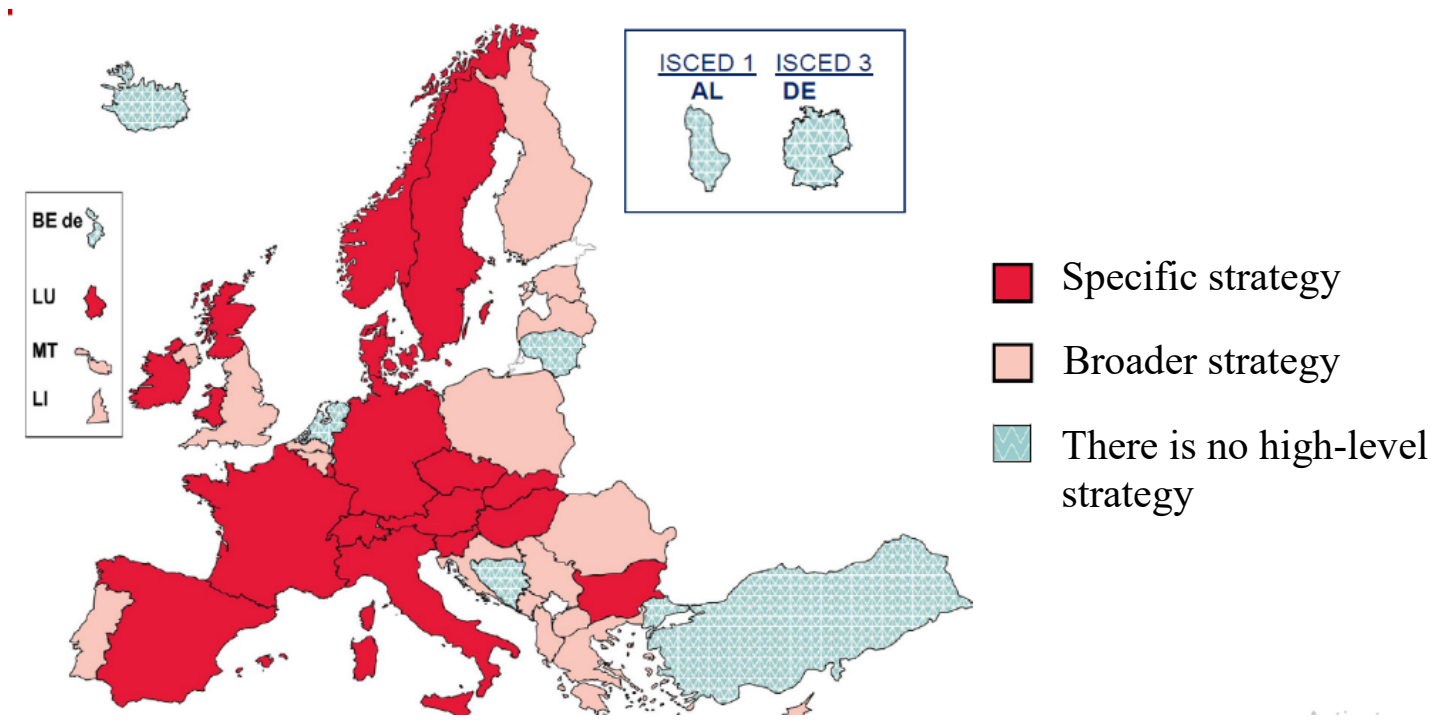

Figure 1. Types of strategies on digital education pre-university education

Source: European Commission / EACEA / Eurydice, Digital Education in Schools in Europe. Eurydice Report. Luxembourg: Publications Office of the European Union (2019, p. 85)

Objectives two and four of the "Action Plan for Education 2019-2030" have in mind the development of the digital environment. Strategic Objective 2 involves "promoting well-being in schools as a prerequisite for improving educational services and for the efficient use of school resources, including the digital environment", and Strategic Objective 4 envisages the development and correlation of modern, digital, monitoring tools. and evaluation in order to provide data for the formulation of strategic directions and solutions for permanent improvement, in partnership with stakeholders, the quality of the public education service "(Ministry of National Education, 2019).

In September 2019, funding contracts worth almost 100 million euros were signed, accessed from European funds for the programs "School Management Information System - SIMS" and "Digital Platform with Open Educational Resources - Virtual School Library", which demonstrates the interest of state authorities in increasing the quality of education. The SIMS project intends to enroll online in high school, introduce the concept of electronic catalog in all schools and introduce the online evaluation of theses written during national assessments. It benefits from a financing of 225 million lei, and the project "National Education Platform" receives 250 million lei, non-reimbursable European money.

A study conducted at the request of the European Commission and conducted by DG Communications Networks, Content \& Technology by: Deloitt and Ipsos Mori, reveals the situation of the online environment in Romania compared to the European Union. The study from 2017-2018 involved approximately 400 schools in the country and conducted interviews with teachers, students and parents. The International Standard Classification of Education (ISCED) of level 1 (primary education), level 2 (secondary education), level 3 (high school education) (European Commission, 2019 ) is considered. As can be seen in Figure 2, the percentage of schools equipped and connected to the Internet is below the EU level. The level where a higher percentage is registered is the one in university education. For primary and secondary and secondary education we do not reach even half of the European average. 


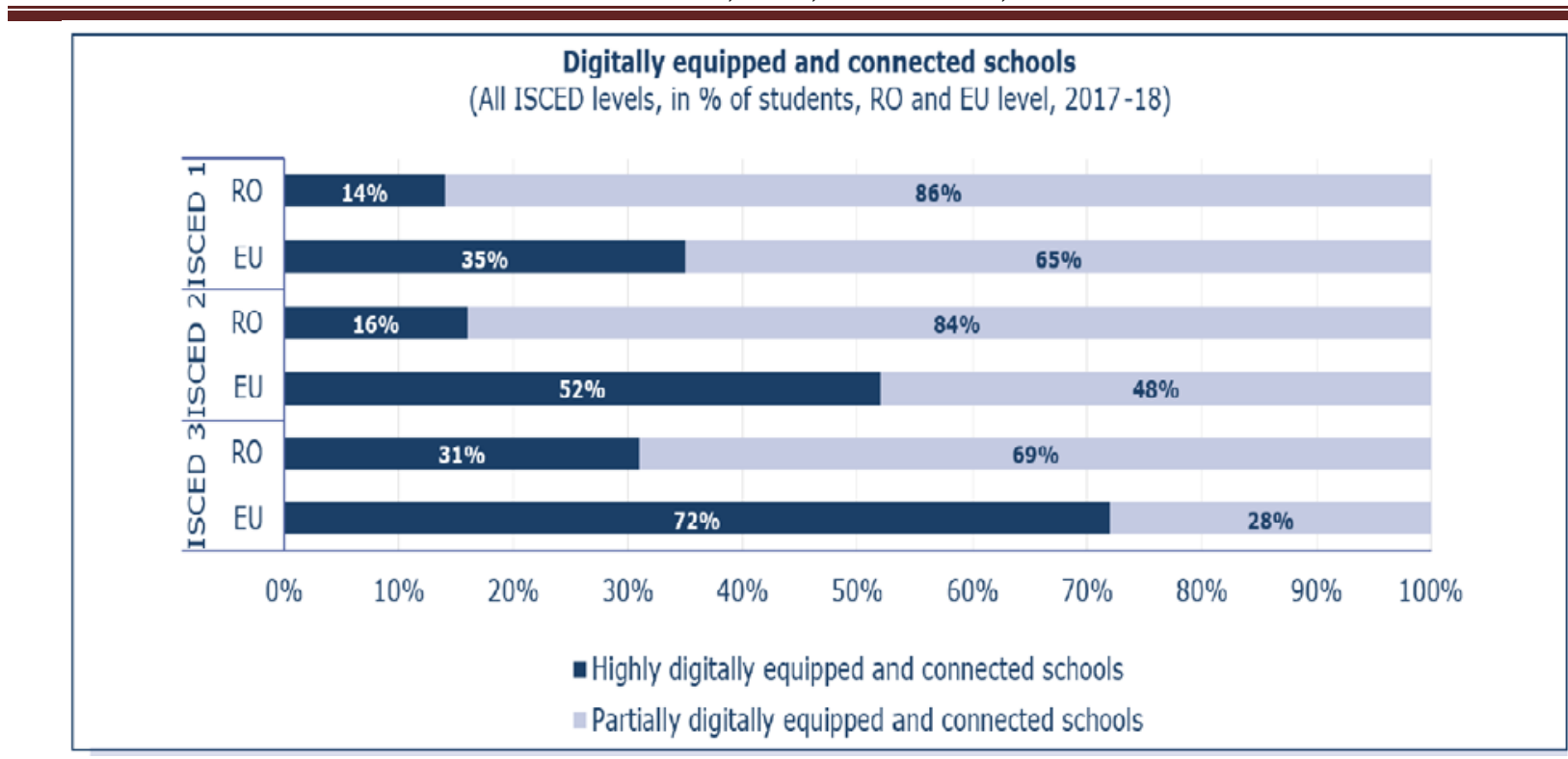

Figure 2. The share of digitally equipped and connected schools

Source: European Commission, 2nd Survey of Schools: ICT in Education-Romania Country Report, Luxembourg, Publications of the European Union $(2019$, p. 7)

In terms of internet speed in schools, Romania ranks quite well, recording percentages similar to those in the EU, and sometimes even higher, as shown by Figure 3. A higher rate for all ISCED levels refers to the connectivity of high speed over 100 mbps.

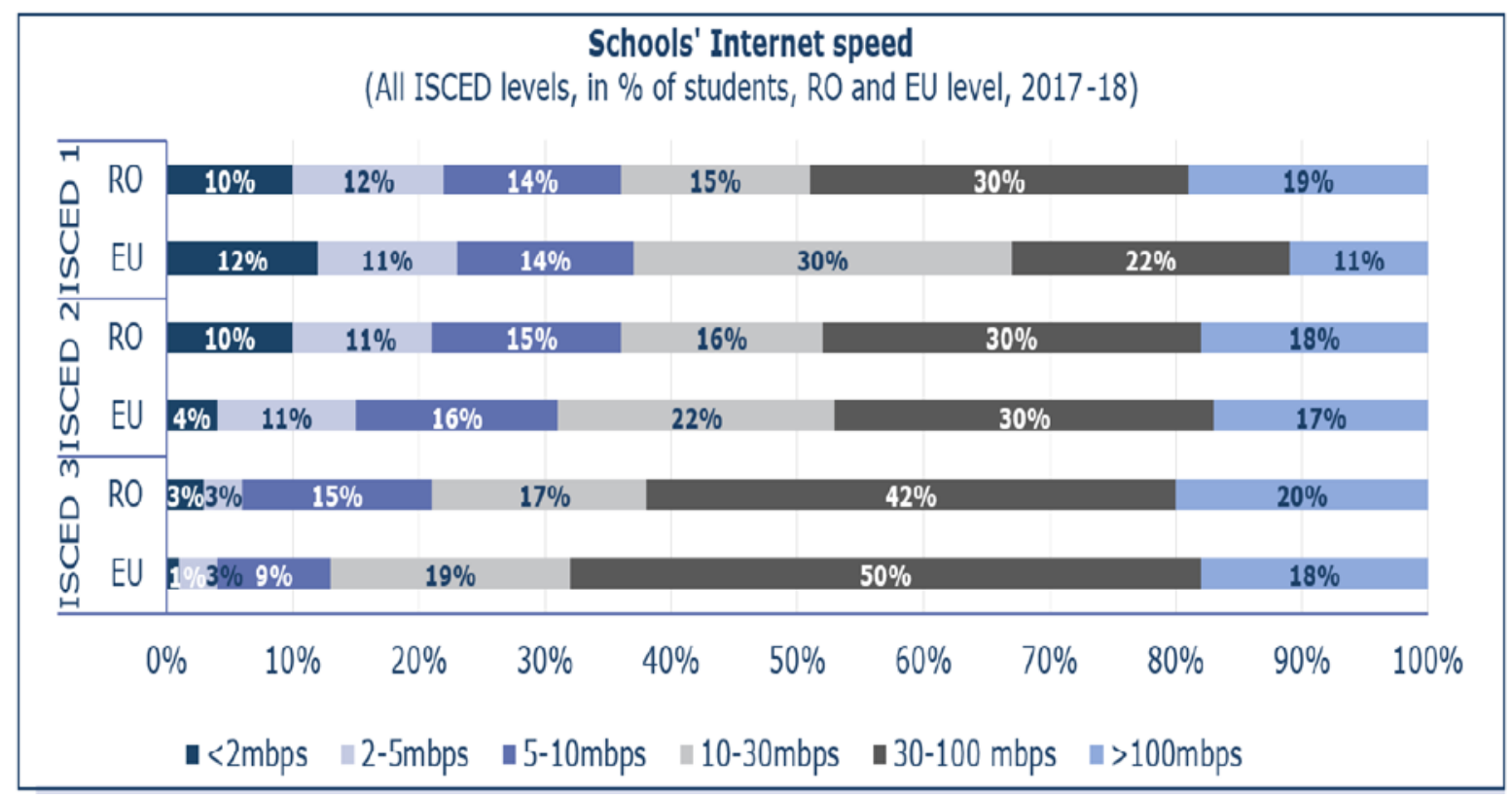

Figure 3. The speed of the internet in schools

Source: European Commission, 2nd Survey of Schools: ICT in Education-Romania Contry Report, Luxembourg, Publications of the European Union (2019, p. 8)

The study shows a higher share of use of own smartphones in Romania compared to the European average for ISCED, level 2 and 3. For ISCED 2 there is a lower share of tablet and laptop use, and for ISCED 3 a share higher laptop and tablet usage, as shown in Figure 4. 


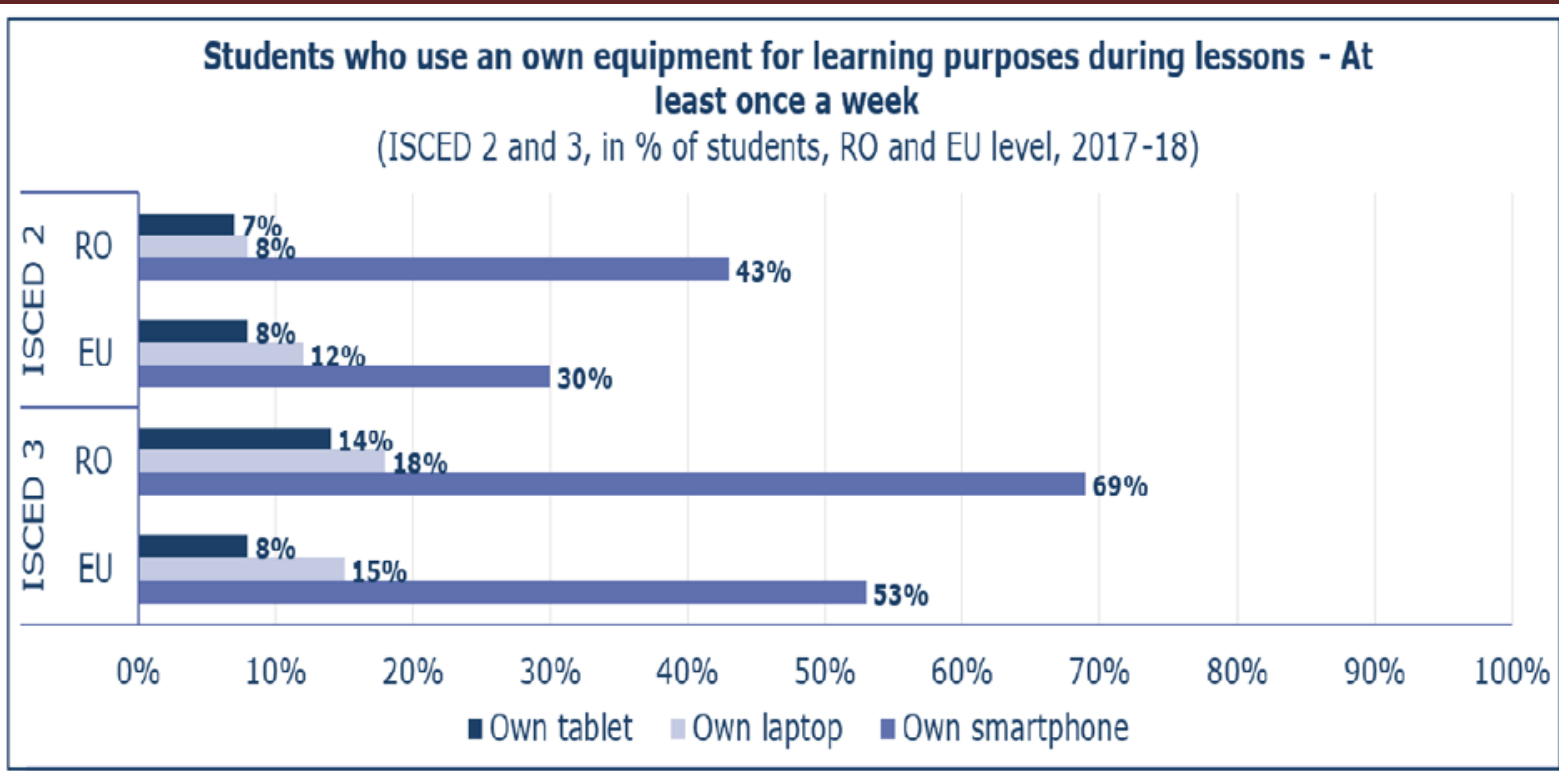

Figure 4. Own equipment used for learning

Source: European Commission, 2nd Survey of Schools: ICT in Education-Romania Country Report, Luxembourg, Publications of the European Union (2019, p. 10)

\section{SARS-CoV-2 PANDEMIC WORLDWIDE AND AT EUROPEAN LEVEL}

The SARS-CoV-2 pandemic has put education systems around the world to the test. Digital education has moved abruptly and widely, including through online learning and teaching. This highlighted the fact that resources and infrastructure were not being developed. Hence the fact that many students were excluded from access. In addition, many teachers, students, parents were not prepared to use online learning and meet its requirements. Figures 4 and 5 show a comparative analysis 3 months apart. In July 2020, compared to April 2020, there is an improvement of students affected by the situation of schools, decreasing by about $47.02 \%$. And in terms of closed educational units, there is a decrease of $57.83 \%$. The same decreasing trend has the percentage of $-28.7 \%$ of the total number of students affected by the coronavirus pandemic.
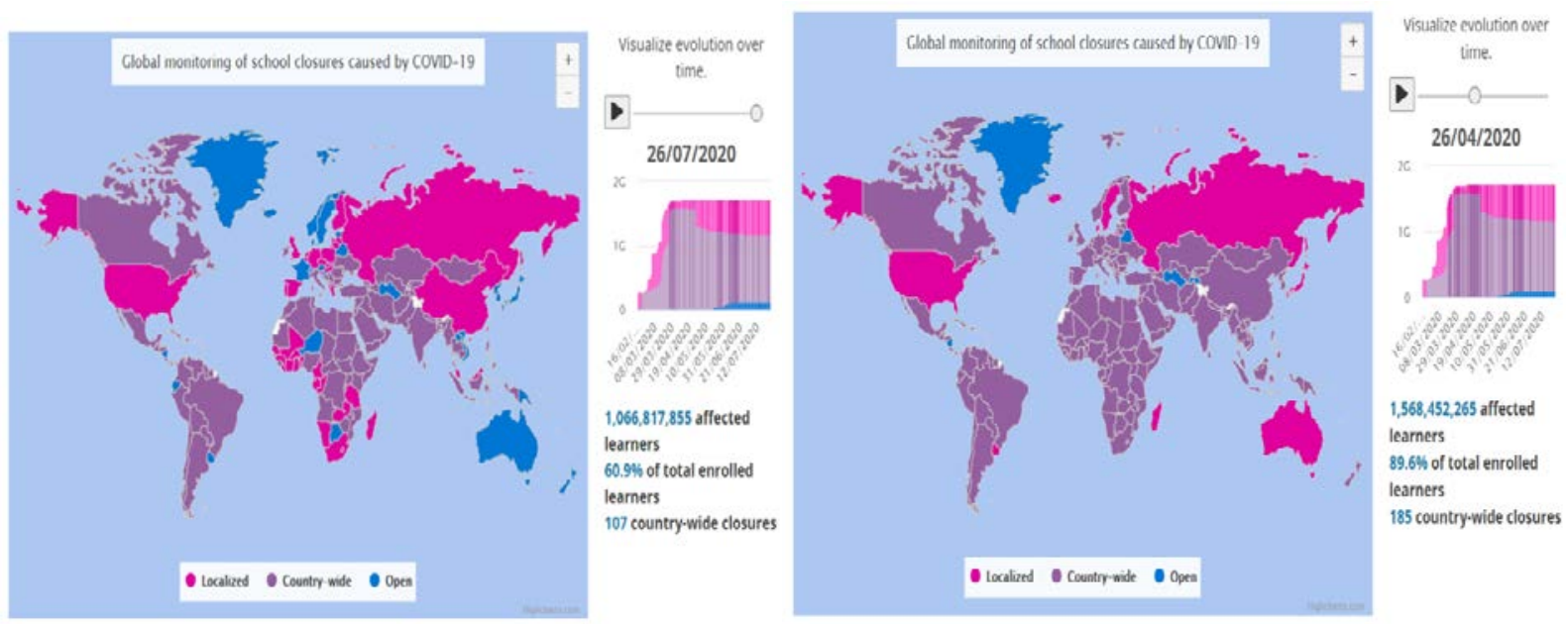

Figure 5. The situation of educational units during April-July 2020 Source: https://en.unesco.org/covid19/educationresponse 
Within the European Union, Member States' measures on education have been different, each taking into account the number of illnesses and the situation at national level. In the vast majority of European countries, it has been decided to physically close the institutions that provide education and move to distance learning with the help of digital opportunities. This situation has resulted in a digital transformation of schools. In this sense, efforts have been made to adapt and prepare the educational content for distance learning. An online platform "School Education Gateway" was created, which considers primarily teachers, but also students and parents. The platform includes sections on online seminars, examples of good practice, open educational resources, online courses, opinion polls. A European School Kit has been set up, which is broken down by area of expertise.

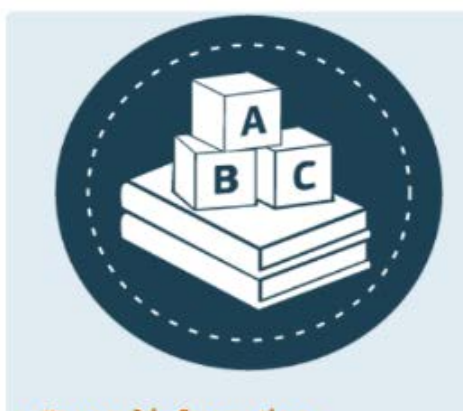

General information

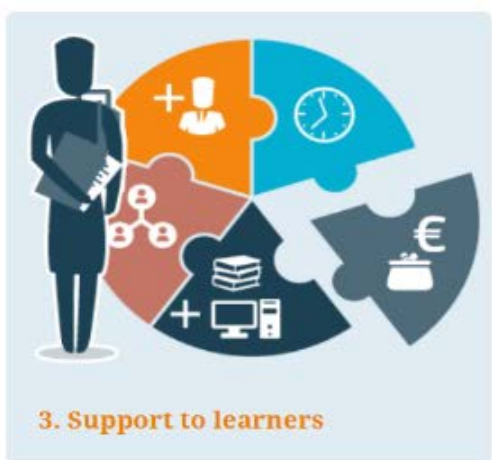

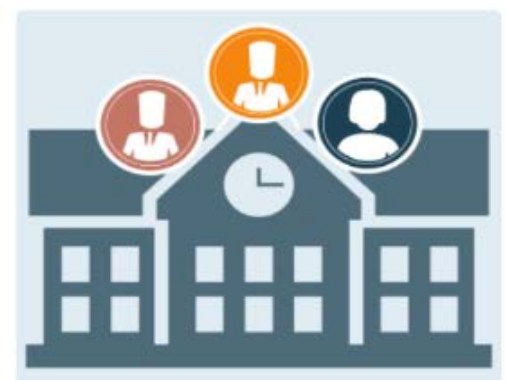

1. School governance

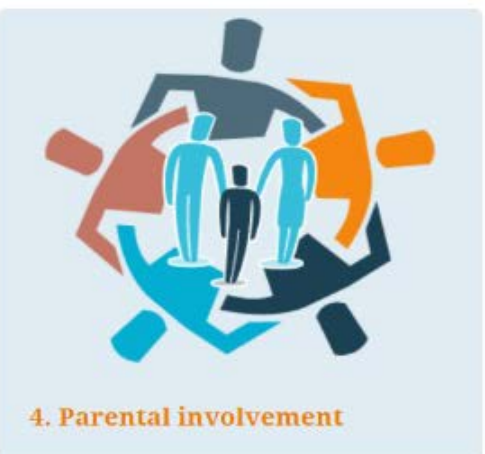

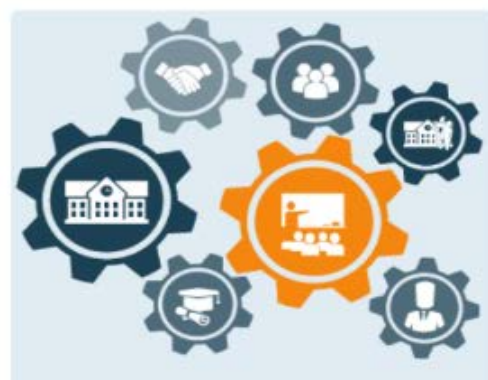

2. Teachers

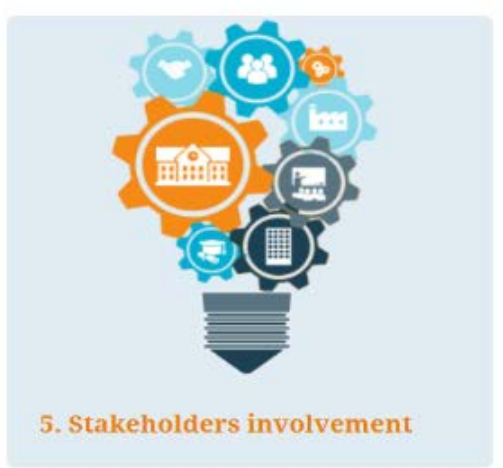

Figure 6. Sectors in the School Toolkit

Source: https://www.schooleducationgateway.eu/en/pub/resources/toolkitsforschools.htm

On 18 June 2020, the European Commission is launching a public consultation on a new Digital Education Action Plan (https://ec.europa.eu/commission/presscorner/detail/en/IP_20_1066, 2020). Solutions need to be found on the following issues:

- transformed digital capacity to overcome discrepancies regarding infrastructure, tablets, laptops, broadband access. It is also necessary to encourage a new organizational capacity in education to help hybrid modes of learning, online and offline;

- digital skills for the 21 st century, with express reference for teachers to be supported to correlate online and offline education taking into account the needs of students. Developing an understanding of the digital world for critically addressing the information found on web pages.

- the digital ecosystem of educational content, tools and platforms must include social issues and maintain confidentiality and ethics. The digital ecosystem is based on public and private resources, secure platforms and easy-to-use tools (Digital Education Action Plan Update, 2020). 


\section{NATIONAL INITIATIVES TO COUNTER THE EFFECTS OF THE SARS-CoV-2 PANDEMIC IN THE FIELD OF EDUCATION}

The health crisis that culminated with the international declaration of the SARS-CoV-2 pandemic coincided for Romania with the decreeing of the state of emergency by Decree no. $195 / 16.03 .2020$. The consequence for the education system was the suspension of courses. Decree no. $240 / 14.04 .2020$ extends the state of emergency until May 15 and article 78 stipulates that the educational activities will be carried out in online format.

Given the situation created by the introduction of the State of Emergency caused by the SARS-CoV2 pandemic, SAMRO postpones a series of discussions and debates towards the end of September 2020 by organizing the "National Economic Forum". Specialists from all fields, including education, are invited to express views, leading to the identification of concrete solutions to get out of the crisis. Two directions of action are envisaged. The first directive refers to "continuing to fulfill the current essential obligations as teachers, consultants and / or managers in organizations in the new conditions: online courses, online consultations, materials and teaching approaches specific to online use, maintaining the functioning of the led field." The second directive refers to "the preparation of new managerial approaches - conceptual, methodological, operational and pragmatic, which are necessary for both exit from crisis and post-crisis management." (Nicolescu, 2020)

In this sense, an essential role belongs to managers from all sectors of society to make decisions in line with the new reality. Managerial education is becoming increasingly important in the training of managers. An important aspect identified by specialists in the field of managerial education refers to the complex impact that this crisis has on society in general, but also on the response reactions. All the more so in the field of education, probabilistic and non-linear thinking must be developed, which will prepare future managers for prompt reactions of response and increased adaptability under the rule of systemic thinking (Brătianu, 2020).

In education, including managerial education, measures must be taken to increase the role of technology, change the role of teachers adapted to the new situation, develop the speed of knowledge flow. Thus, online education can become an asset for universities, with the help of appropriate facilities. Consideration must be given to extending skills adapted to the new context such as entrepreneurial skills, flexibility, emotional intelligence, lifelong learning, the ability to contextualize (Popa, 2020).

The measures adopted by the state authorities in pre-university education were the following:

- suspension of courses that take into account the physical presence of students;

- teaching-learning-assessment for all levels of education online;

- broadcasting on the national television channel TVR2 and TVR3 some lessons for the 8th and 12th grades, respectively for the subjects for which national exams will be taken;

- concluding school situations for all students;

- taking the National Assessment, the Baccalaureate Exam and the Certification Exams of professional competencies for level 3,4 and 5, according to the National Qualifications Framework, in safe conditions for all students (Ministry of Education and Research, 2020).

In the online study, the Ministry of Education and Research opened the "Digital on educred" portal. The resources made available to teachers, students and parents were taken into account:

- platforms for class management considering those implemented at national level: google classroom / G - Suite, Edmodo, Moodle, kinderpedia, easyclass, edus, Adservio;

- other platforms and applications in Romanian such as a library with digital educational content;

- textbooks in digital digital format (https://eduonline.roedu.net/, 2020);

- resources for learning activities - Institute of Education Science, which consider resources for primary education, test sets and a series of documents developed in partnership with UNICEF ISE;

- the platform that incorporates approximately 800 ideas of learning activities with digital tools; 
- online tools for learning platforms: padlet, edpuzzle, microsoft powerpoint, google slides, bubbl.us, etc.;

- communication tools: Google Meet, Microsoft Teams, Zoom, WebEx, YouTube;

- peer support groups such as the CRED project group, the open educational resources group, the Romanian teacher's group (https://digital.educred.ro, 2020).

\section{CASE STUDY REGARDING ONLINE EDUCATION CARRIED OUT WITHIN THE TECHNOLOGICAL HIGH SCHOOL "TUDOR VLADIMIRESCU" IN THE CLASSES PROFILE SERVICES, TECHNICIAN SPECIALIZATION IN TRADE ACTIVITIES}

In the second semester of the 2019-2020 school year, a state of emergency was declared at national level as a result of the SARS-CoV-2 pandemic. The novelty of the health crisis revealed that the Romanian education system was not prepared for online distance learning. Given the exceptional situation, there was a moment of chaos, the schools not knowing what measures to take. For teachers it was a time to look for digital solutions, and for students it was considered a break, an anticipation of the holiday. The Romanian education system was too unprepared to make the transition to the online part of teaching, and the predominant mentality was that of carrying out the educational act in the traditional way, respectively face to face.

With the declaration of the state of emergency in March and the suspension of the courses, the groups corresponding to the classes were created at the high school level with the help of WhatsApp, Facebook, messenger applications. At the same time, the ZOOM audio-video synchronous application began to be used. Each teacher used at that time the applications he considered necessary. In our case, we also tried to use the Moodle platform, which was already functional, but very few students logged in and accessed the courses. Most students preferred to communicate through the mentioned applications.

Towards the end of April, an order was given by the Minister of Education to stipulate the compulsory nature of online education. At the same time, there was an approach at the level of the high school management for the acquisition of the field and the use of the G Suite for Education package for all high school students and teachers. At the high school level, each class was organized with the help of the head teacher through Gmail addresses for the lttvgl.ro domain, to which all students and teachers who teach in that class had access. In this way, the development of lessons at a centralized level began, with virtual classes.

For the modules specific to the technical specialization in trade activities, the ninth, tenth and twelfth grades of the lessons were carried out in accordance with a schedule and the plans in force, as can be seen in Figure 7.

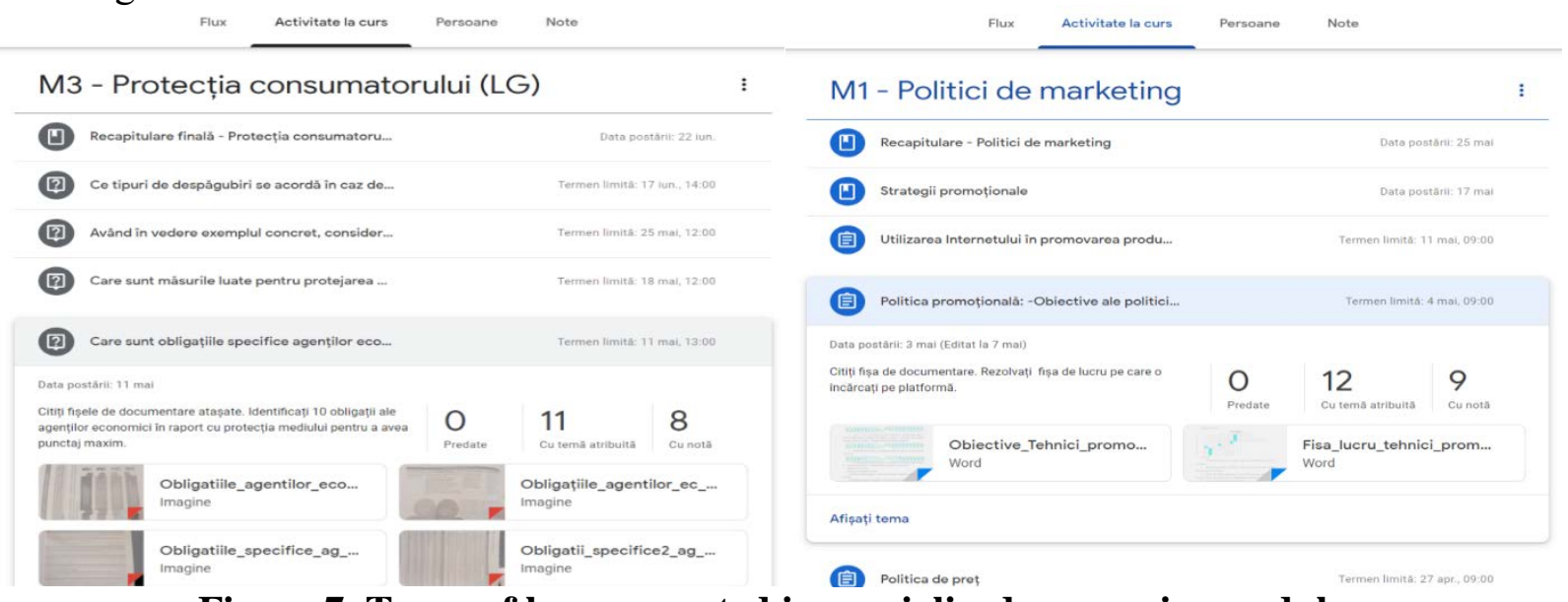

Figure 7. Types of lessons posted in specialized economics modules

Source: https://classroom.google.com/u/1/w/OTMyOTYwNDg3MDBa/t/all 
At the end of the courses, an online questionnaire was applied to the students from the three classes with service profile, technical specialization in trade activities regarding distance learning and the online environment. The questionnaire had 10 questions. 60 respondents out of 65 possible answered, which shows a participation of $92.30 \%$.

Regarding electronic devices, $93.3 \%$ said that they have an android phone, 3.3\% a simple phone, $1.7 \%$ a tablet, $36.7 \%$ a laptop and $23.3 \%$ have a personal computer, as a figure 8 also shows. $85 \%$ of students make an internet connection using $\mathrm{Wi}-\mathrm{Fi}$, and $15 \%$ via mobile data. The quality of the data transmission speed was considered good by $40 \%$ of the respondents, very good by $11.7 \%$, the excellent response receiving $8.3 \%$. The connection is felt as weak by $33.3 \%$ of students, and $6.7 \%$ perceive it as very weak.

\section{0 responses}

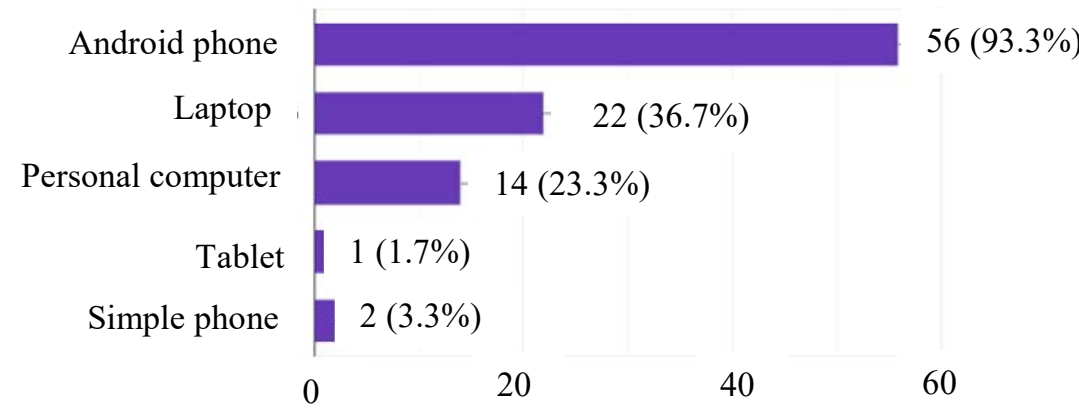

Figure 8. Electronic devices owned by students in economic classes

Source: https://docs.google.com/forms/d/1dbxQSq0J_WVKfH_EkNASprU2hT_V9pdmDp1Wp8T4bQ/edit\#responses

Regarding the way students like to learn online, 53 of the students say that online platforms and applications are the most popular. The answers are highlighted in the figure 9.

\section{0 responses}

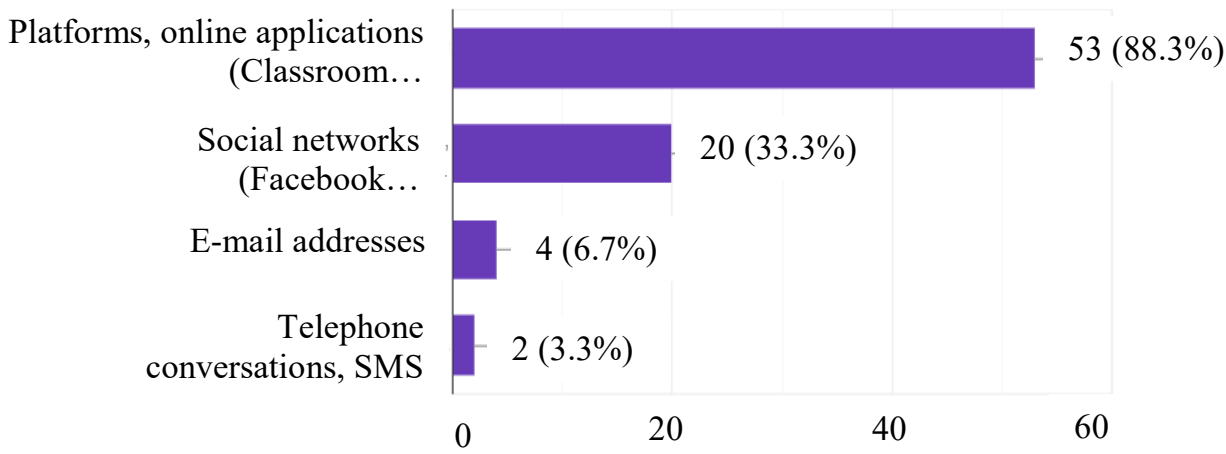

Figure 9. Ways to achieve online learning

Source: https://docs.google.com/forms/d/1dbxQSq0J_WVKfH_EkNASprU2hT_V9pdmDp1Wp8T4bQ/edit\#responses

Of the online audio-video synchronous applications used during this period at the high school level, ZOOM obtains 56.7\%, MEET 33.3\%, and Skype only 10\%. As you can see, even if the MEET application is integrated into the google classroom platform, which is the students' favorite, it does not get the majority vote. The highest number of votes is obtained by the ZOOM application, which was used by several teachers before the implementation of the classroom platform at the level of the entire school institution. 
Regarding the frequency with which the students interacted with the teachers during the live lessons, the majority percentage is that of the weekly response in proportion of $70 \%, 21.7 \%$ entered daily, $6.7 \%$ monthly and never $1.7 \%$. This highlights the technical and equipment difficulties encountered by students in the online environment regarding the lack of computers, tablets, but also the interruption of electricity weekly or even several times a week. Another aspect that needs to be emphasized is that of the number of children in a family. Even if there is another laptop next to the android mobile phone, or another tablet in the family, which of the children has priority to connect first to the lessons? This explains the answers given by students in economics classes regarding course attendance.

Among the means used in the teaching-learning process by teachers, $78.3 \%$ of the students chose the educational platforms, saying that they helped them to acquire knowledge during distance learning. $50 \%$ of the students considered that the tutorials or videos also helped them to acquire knowledge. Live lessons occupy a fourth place in the preferences of students, with $23.3 \%$, but this answer must be correlated with the daily participation rate in online lessons which is lower.

The evaluation method most appreciated by $76.7 \%$ of students was the one related to a topic / essay / essay uploaded online at a deadline. Another way considered favorite, $51.7 \%$, was the short answer to a certain question. $20 \%$ get the test online and only $1.7 \%$ the oral assessment in live classes.

Interesting to watch are the answers to the question of whether distance learning has managed to cover educational needs, shown in Figure 10. 30 students chose the middle option, average answer, 12 students said a lot, and 15 students considered only little bit. No answer was given by 1 student, and a lot of 2 students.

\section{0 responses}

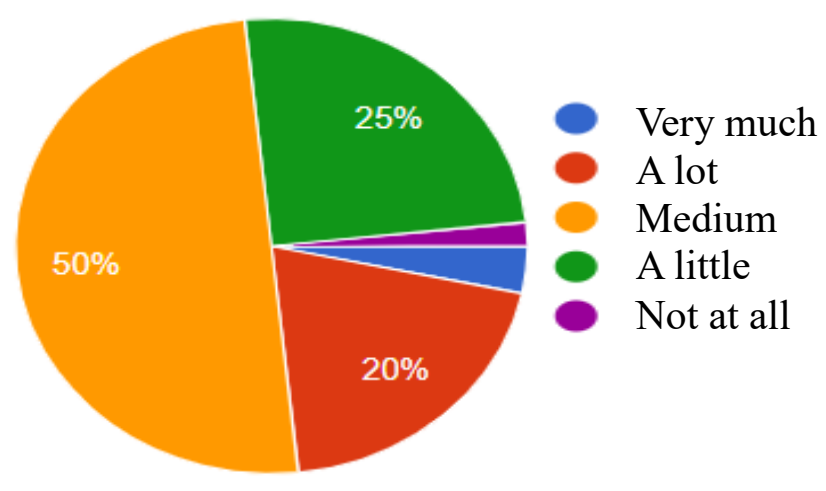

Figure 10. Students' perception of meeting educational needs

Source: data processed by the author

The question that can give a suggestion to the rulers on how to carry out education in the next school year refers to the possibility that the online environment remains a part of learning, highlighted in Figure 11 . As can be seen a 55\% majority answered yes, and the others said no. 


\section{0 responses}

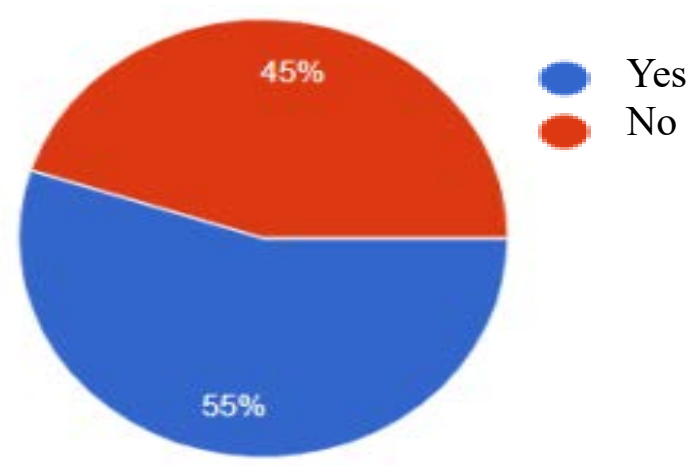

Figure 11. Students' opinion about online education as part of learning Source: data processed by the author

Among the suggestions for improving the online environment offered by students we can list a strict schedule, fewer homework, the program to start later, students who do not participate to be absent, more fact sheets with explanations and more power point presentations. Some students did not propose a way to improve and $31.67 \%$ only suggested traditional education.

\section{QUESTIONS AND DISCUSSION TOPICS}

In view of the above, some questions need to be asked about digital education that we will try to answer. We consider that the proposed solutions are applicable not only for the period immediately following, but whenever the situation requires it.

1. How can the material base of educational units be improved in the next period?

An essential element for the resumption in good conditions of traditional education, face to face, is the logistics available to educational institutions in Romania. We will take into account especially the situation in rural areas, where circumstances are more complicated. A first aspect is the one regarding the classrooms, which are quite small in space and insufficient in number. They do not physically allow a social distance of 2 meters per person, as stipulated by current health regulations. Even in the case of adopting a hybrid model, in which half of the students are in the classroom and the other half are at home, the students' electronic devices are missing or insufficient. A second element is the one related to the endowments with electronic equipment (laptop, tablets, desktop) and the internet connectivity. Computer labs exist, theoretically, in all schools. Basically, some of them are outdated morally and physically. In this sense, the amendment of Law no. 1/2011 of the National Education which provides for the provision on request of a laptop or a tablet with internet connection. These devices will be part of the schools' heritage. The Government's response was a reserved one, the motivation being that a series of financial measures have been adopted for the crisis situation, there is already a budget deficit of $6.7 \%$ of GDP and there are no immediate solutions for additional budget revenues. The next question is where can the funding come from? The underfunding of the Romanian education system is known. It allocates very few resources to education from GDP, in 2019 it allocated 3.02\%, of which, at the first rectification, the funds were reduced, reaching 2.9\% of GDP. Although Law no. 1/2011 of education, provides in art. 8 that the financing be of $6 \%$ of the GDP, this provision is further suspended by the provisions of GEO no. 114/2018.

A solution with immediate applicability would be changes to projects with global and European funding for which funds have already been accessed, such as the Secondary Education Project (ROSE) under the high school grant scheme, the Horizon project, etc. To implement changes to these projects, in In line with current requirements, flexibility must be applied to change activities 
that can no longer be carried out or that are difficult to carry out and to reallocate those amounts to the digital endowment of schools. Another solution would be national, regional or local actions carried out by reputable companies or NGOs to support educational institutions to ensure appropriate digitization.

2. What are the alternatives for conducting courses, if face-to-face education cannot be achieved?

From the applied questionnaire results a request of students for face-to-face education. The period March-June 2020 in which online education took place highlighted all the shortcomings related to this situation. The situation in the rural environment is even more pronounced where students have a lower motivation regarding learning, the risk of dropout is high, being supported by precarious financial aspects. It is even more difficult the situation of students living in environments where the risk of poverty and social exclusion is high, of students living in families that do not provide an environment conducive to individual study at home and based on free meals at school. The high school that is the subject of the case study provides a hot meal to students involved in remedial activities through the ROSE project.

Another perspective that must be taken into account is that of the parents, who were put in the situation of completing together with their children the worksheets and their support during the online lessons. Sometimes, especially in disadvantaged environments, it has been found that some families do not have access to technology, the internet or do not have digital knowledge. The consequence was a sustained effort, especially if there were more children in the house. If parents were at work, then children had difficulty participating in online lessons, and finding an alternative day care for younger children was an additional concern, both psychological and financial for parents.

Another aspect was the mentality. For the Romanian society, there is no distance learning experience. This type of education has been used very rarely among students in pre-university education. If they are not present in high school, students feel that they are not required to attend online courses. The statements of the authorities and interpretations from the press and social networks contributed to the strengthening of this belief. Not being physically at school, some students consider themselves on vacation and have the perception that they can do whatever they want, without having to attend online courses. To these are added the challenges specific to adolescence that contribute to lower school performance. It should also be mentioned the specific mentality of the rural environment, in which adolescents are required in household chores or for various agricultural work.

The measures to be adopted must be at national level, but at the same time provide alternatives by which the boards of directors can choose the optimal and safe health, social and educational option for the educational institution concerned. There is clearly a discrepancy between rural and urban areas. In cities, the classes are more crowded with a larger number of students, but also with appropriate facilities. In rural areas, some classes have fewer students, but the facilities are insufficient. An already individualized solution would be to alternate students, some to be physically in the classroom, others to be at home. This can be done by rotation, every few days, every week or two. If this is to be done, the timetable must be clear and attendance at online courses must be compulsory for students staying at home. For the rural environment, the optimal option would be that of physical presence in schools.

The exclusive version of online education would not be desirable. Insufficient devices, lack of parents' time, their training, lack of connectivity, lack of motivation, students who are not used to studying only from home, not understanding how some applications work, are some reasons to avoid this choice. If the health situation so requires, it becomes clear that a number of strict rules must be adopted. Students cannot sit in front of a computer from 8.00 to 14.00 , if we take into account the contraindicated effect in this regard. At the same time, the students' strength of concentration weakens and fatigue intervenes. For this reason, the hours should be shortened, to have a maximum of 30-40 minutes with minimum breaks of 10 minutes. 
3. Are teachers methodologically prepared for online lessons?

For online teaching, there is an adaptability and creative effort for teachers. It is noted that not all teachers have the knowledge, skills, abilities, confidence and experience to conduct online courses. The hasty transition to digital education without a characteristic training does not mean that the general standard for distance learning is reached. It is a certainty that in order to adapt to the requirements of digital education, teachers have made extra efforts that have led to an increase in workload. In this sense, the dedication, mutual learning, collaboration between teachers, learning, often individual, of the operation of different types of online platforms and applications are highlighted.

As for the didactic design, it must be modified, it can no longer be carried out in the same way as in traditional education. Certain stages of the lesson can no longer be carried out or can be carried out succinctly. The methods must be adapted to the digital and student requirements. Some methods require adaptations and improvements. Means and tools with a strong visual and auditory impact must be used to attract attention and stimulate motivation for learning. In this sense, it is desirable to debate the specialists in the field and offer concrete design variants of some lessons or excerpts of lessons. The training courses must be carried out centrally and as urgently as possible with applicability for each subject. It is necessary to increase the number of digital textbooks (for technological high schools, service profile, there is no digital textbook, according to the new school curricula) and open educational resources.

\section{Are educational institutions ready to receive students in the new conditions of social distancing?}

The manner in which the new school year will begin must be announced before 1 September. The same must be done for any change that occurs during the school year. Managers must be allowed to start procurement (for disinfectants and cleaning materials, masks, etc.), they must prepare special color spaces, make decisions on how to carry out their teaching activity, update online educational platforms with new study groups or to acquire domains in order to implement an educational platform. We know from previous experience the blockages of several weeks that took place in accessing accounts and passwords for various educational platforms and this is to be avoided for the future. We realize that the situation of the health crisis has a rapid dynamic, but knowing so far, a number of aspects characteristic of coronavirus, predictability is needed to give school managers the opportunity to adopt the best solutions. In this regard, reasonable time should also be given to parents to find solutions for young children, especially given that they have a job that requires their physical presence.

\section{CONCLUSIONS}

There is a constant and urgent need to have an education that welcomes and supports the future, especially the digital one. The health crisis has highlighted the need for a solid digital capacity and first-rate digital skills for the continuity of education. The physical closure of schools has triggered an urgent response from educational institutions by offering alternative solutions to distance education, especially through digital options in order to safeguard the right to education. Adherence to the principle of equity must be an important factor in eliminating socio-economic disparities between urban and rural areas.

Following the case study analyzed and the questionnaire applied to rural students in a technological high school, service profile, trade, online education proves to be difficult to achieve for the following reasons: most students have smartphones, but not sufficiently developed to replace a computer staff (which would be more appropriate for the requirements of high school education); the computers they own are not always equipped with the Office suite and are not powerful; there are several children in the family, who request the electronic device at the same time; the internet connection is average in speed, often unstable, which sometimes makes it impossible to participate in live lessons with the 
help of Meet and Zoom applications; difficulties in understanding how the google classroom platform works and the different applications; the information is transmitted on the class groups (WhatsApp, on messenger, Gmail addresses), but also on the classroom platform, which generates extra effort and time on following them; the fairly frequent interruption of electricity, due to infrastructure works, which made it impossible for some students to participate in online courses; low motivation for learning, to which is added the partial and sometimes erroneous information transmitted in the press and on social networks; some students are engaged by their parents in household and agricultural work in rural areas; students agree that online learning should remain part of traditional learning, but this should prevail.

The SARS-CoV-2 pandemic exposed the difficulties of inclusion, access and equity, with students encountering difficulties in accessing appropriate digital devices, with reliable Internet connectivity and the existence of a supportive learning environment. Teachers faced the need to learn quickly and use new technologies effectively to support students in educational activities. The situation has shown that educational institutions need rapid support to increase technical equipment in support of digital education, but also the skills and training of teachers to use them in optimal conditions.

Real support for increasing the digital capacity of educational institutions through the exchange of good practices, professional development, cooperation, new ways of digital education is desirable. Digital literacy needs to be implemented through the development of digital skills and the deepening of computer education. Included in this concept are the use of information and artificial intelligence in education, the application of ethical standards in the use of data, the understanding of misinformation tactics and fake news. Added to these goals is the realization of a reliable digital ecosystem built with innovative applications, quality content and secure online tools, in line with the EU's objectives on digital education.

It must be borne in mind that higher quality education helps the professional and personal development of citizens and the endurance of the economy and society, providing real support for recovery and overcoming the current crisis.

Although digital education has contributed to ensuring the continuity of the teaching-learningassessment process during the suspension of courses, online education, conducted at a distance, cannot replace the quality of the face-to-face educational act. Online education must be an integral, complementary and helpful part of education done directly in the classroom. The motivational role, of stimulating the interest, of the students' creativity, the psycho-social connections that are created by the physical presence in the classroom of the teachers and students are irreplaceable.

\section{REFERENCES}

Amza, C.G., Cantemir, D., Cantemir, I., Oikonomoula, A., Poterucha, P., Salucci, et al. (2018). Ghid de antreprenoriat bazat pe Industria 4.0 și drone, pentru cursanții din Educația și Formarea Profesională. Rzeszów, Polonia: Editura: Danmar Computers.

Brătianu, C. (2020). Criza generată de COVID -19 și impactul ei asupra educației manageriale din România. Retrieved July 20, 2020, from http://samro.ro/wp-content/uploads/2020/06/Crizagenerata-de-COVID.pdf.

Bologa, R. (2019). Profesiile industriei 4.0, Retrieved July 20, 2020, from https://intelligence.sri.ro/profesiile-industriei-4-0/.

European Commission (2017). Un document de reflecție privind digitalizarea, capacitatea de inserție profesională și incluziunea. Rolul Europei. Retrieved July 15, 2020, from http://ec.europa.eu/newsroom/document.cfm?doc_id=44515.

European Commission (2019). Educația digitală în școlile din Europa.Raport Eurydice. Luxemburg: Oficiul pentru Publicații al Uniunii Europene. Retrieved July 29, 2020, from https://op.europa.eu/en/publication-detail/-/publication/d7834ad0-ddac-11e9-9c4e01aa75ed 71a1/language-ro/format-PDF. 
Diac, M. (2019) (in press). Impactul revoluţiei digitale asupra omului şi societăţii. România Liberă.

Digital Education Action Plan Update (n.d.). In Europa.eu. Retrieved July 27, 2020, from https://ec.europa.eu/info/law/better-regulation/have-your-say/initiatives/12453-Digital-

Education-Action-Plan

European Commission (2019). 2nd Survey of Schools: ICT in Education. Romania Country Report. Retrieved July 27, 2020, from https://ec.europa.eu/digital-single-market/en/news/2nd-surveyschools-ict-education.

Ministerul Educației Naționale (2019). Planul de acțiune pentru educație 2019-2030, Retrieved July 15, 2020, from https://www.edu.ro/sites/default/files/Plan\%20actiune\%20educatie.pdf.

Ministerul Educației și Cercetării (2020). Ghid informativ MEC în contextul COVID - 19. Retrieved July 10, 2020, from https://www.edu.ro/ghid-informativ-al-mec-\%C3\%AEn-contextul-covid19.

Nicolescu, O. (2020). Feedbackul specialiștilor și comunității SAMRO în condițiile pandemiei coronavirus. Retrieved March 20, 2020, from http://samro.ro/wpcontent/uploads/2020/03/Invitatie-la-dezbatere-a-membrilor-SAMRO.pdf.

Pop, A.B., Tîțu, M., Oprean, C., Ceocea C., Sandu, V.A. \& Tîțu, Ș. (2018). Contribution concerning the possibility of implementing the APQP concept in the aerospace industry. Paper presented at The $22^{\text {nd }}$ International Conference on Innovative Manufacturing Engineering and Energy IManE\&E 2018.

Pop, A.B, Tîțu, A.,M., Pop, G.I., Ceocea, C. \& Țîțu, Ș. (2019). Research Design and Identification of the Project Methodology Solutions Using the Finite Element Method. Joint Conference on Green Engineering Technology \& Applied Computing 2019. IOP Conf. Series: Materials Science and Engineering. doi: 10.1088/1757-899X/551/1/012130

Popa, I. (2020). Impactul noului Coronavirus COVID-19 (SARS-COV-2) asupra managementului organizațiilor și pregătirii manageriale universitare. Retrieved March 20, 2020, from http://samro.ro/wp-content/uploads/2020/03/Invitatie-la-dezbatere-a-membrilor-SAMRO.pdf.

European Commission. (2020). European Commission launches a public consultation on a new Digital Education Action Plan. Retrieved July 27, 2020, from https://ec.europa.eu/commission/presscorner/detail/en/IP_20_1066

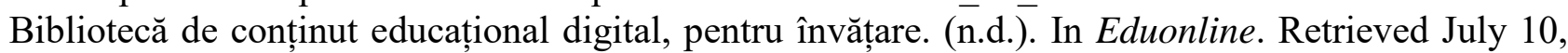
2020 from https://eduonline.roedu.net/

Digital pe educred.ro, «site în dezvoltare cu contribuții deschise». (n.d.) In Digital pe educred. Retrieved July 10, 2020 from https://digital.educred.ro

Platformă de e-learning gratuită pentru elevi. (n.d.) In platforma de e-learning gratuită pentru elevi. Retrieved July 10, 2020 from https://geanina-lupu.ro/

Infrastructură in Educaţie. (n.d.) In Infrastructura in educatie. Retrieved July 15, 2020 from http://sig.forhe.ro/ 